\title{
Redefining Paracoccus denitrificans and Paracoccus pantotrophus and the case for a reassessment of the strains held by international culture collections
}

Donovan P. Kelly, Jean P. Euzéby, Celia F. Goodhew and Ann P. Wood

International Journal of Systematic and Evolutionary Microbiology (2006), 56, part 10, 2495-2500

On p. 2496, the paragraph labelled ' 3 ' should read:

'3. The entry for $P$. pantotrophus should be amended [not 'expanded'] to include DSM 65 and LMG 4218 as valid examples of this species [not 'the type strain'] and the accession number for the 16S rRNA gene sequence of the type strain (ATCC $35512^{\mathrm{T}}$ ) needs to be cited (Y16933).' 